\title{
The role of gender as a moderator in the relationship between disease perception and coping with stress strategies among psychiatric patients
}

\author{
Rola płci jako moderatora relacji pomiędzy obrazem choroby a strategiami radzenia sobie \\ ze stresem pośród pacjentów leczonych psychiatrycznie
}

Marta Kłak ${ }^{1}$ ABDEF, Wioletta Karina Ozga ${ }^{2}$ CDEF, https://orcid.org/0000-0002-7775-0681

${ }^{1}$ Institute of Health Care, State Higher School of Technology and Economics

${ }^{2}$ Institute of Psychology, The John Paul II Catholic University of Lublin

\begin{abstract}
Introduction: The perception of disease depends on the patient's beliefs related to the nature of the illness, the previous personal or family experiences and his/her attitude to them. Patients try to understand and cope with health problems. The purpose of the present study was to answer the question which components of the relationship between the strategies for coping with stress and mental disease perception are moderated by gender.

Material and Methods: The study involved 98 patients with depressive disorders, anxiety disorders, schizophrenia, alcohol related disorders. The research of the variables was carried out using the COPE Inventory and Disease Perception Questionnaire. Results: It has been noticed that in men, when their perception of the mental disorder as beneficial increases, the religious strategies for coping with stress become more frequent. Furthermore, the opposite sex pattern emerged. In the situation when an individual's perception of the illness as a threat increased, female patients less frequently employed religious coping and planning. Furthermore, in women, when the perception of the mental disease as a weakness increases, the frequency of using emotional social support and acceptance decreases.

Conclusions: The result indicated that there are opposite patterns of gender specific coping strategy dependent on the mental illness perception.
\end{abstract}

Keywords: coping strategies, disease perception, mental disorders, moderator, gender

\section{Streszczenie}

Wstęp: Obraz choroby zależy od przekonań pacjenta związanych z charakterem choroby, wcześniejszymi doświadczeniami osobistymi lub rodzinnymi oraz jego postawą wobec nich. Pacjenci próbują zrozumieć i poradzić sobie z problemami zdrowotnymi. Celem niniejszego badania było udzielenie odpowiedzi na pytanie, które komponenty relacji pomiędzy obrazem choroby psychicznej a strategiami radzenia sobie ze stresem będą moderowane przez płeć.

Materiał i Metoda: Badaniem objęto 98 pacjentów z zaburzeniami depresyjnymi, lękowymi, schizofrenią, uzależnionych od alkoholu. Badanie zmiennych przeprowadzono za pomocą Wielowymiarowego Inwentarza do Pomiaru Radzenia Sobie ze Stresem - COPE i Kwestionariusza Obrazu Choroby - KOCh.

Wyniki: Im częściej mężczyźni postrzegają zaburzenie psychiczne jako korzyść, tym częściej radzą sobie ze stresem za pomocą religii. Ponadto, ujawniono odwrotny wzór dla kobiet. Kobiety rzadziej stosowały radzenie sobie ze stresem za pomocą religii i planowania gdy percepcja choroby jako zagrożenia wzrastała. Poza tym, w im większym stopniu kobiety postrzegały chorobę jako słabość tym rzadziej poszukiwały wsparcia emocjonalnego i akceptacji.

Wnioski: Uzyskane wyniki wskazują, że istnieją odmienne wzorce, specyficzne dla płci, stosowanych strategii radzenia sobie ze stresem w zależności od obrazu choroby.

Słowa kluczowe: strategie radzenia sobie ze stresem, obraz choroby, zaburzenia psychiczne, moderator, płeć

\section{Introduction}

Overpowering stress and a fast pace of life promote mental illness. Mental disorders are clinically significant disturbances in an individual's emotion regulation, cognition and behaviour that reflect a dysfunction in mental functioning [1, 2]. Disease is connected with 
subjectively experienced suffering [3]. The perception of disease depends on the patient's beliefs related to the nature of the illness, the previous personal or family experiences and his/her attitude to them [4,5]. To make sense of the symptoms, patients create cognitive representation of their illness [6]. The meaning attributed to the disease depends on how the patient views his/ her mental health problem in a subjective life's context [7]. The illness may be treated as a benefit, a threat, a weakness or a task $[8,9]$. The illness is treated as a benefit if, as a result, a patient receives attention and care. The disease is necessary to escape from the problems and responsibilities of a daily life. The patient's sense of depression, helplessness and anxiety is characteristic if the illness is seen as a threat. In this situation, the disease limits activity in all dimensions of life. If the illness is treated as a weakness, patient refuses a diagnosis and trivialises the symptoms. Perceiving the disease as a task, individuals search for the information about its ethology and symptoms, and try to cope with the problem.

Based on a self-regulation theory of illness perception, individuals try to understand and cope with health problems [6]. According to the Common-Sense Model (CSM) of illness, perceptions of the disease and coping strategies are closely related $[10,11]$. Specific activities undertaken by a person to deal with difficult situations are referred to as coping strategies. A metaanalytic review concerning suffering from a physical illness revealed that various components of the illness perceptions were associated with cognitive reappraisal, avoidance, expressing emotions, and problem-focused coping strategies [12].

The CSM was also carried out on patients suffering from mental disorders [13-15]. The results suggest that individuals suffering from mental disorders use maladaptive ways of coping with stress [16-18]. The high depressive individuals have a tendency to use the avoidant coping strategies [19]. The emotion-focused coping such as avoidance or venting disengagement are predictors of higher levels of anxiety and neuroticism [17, $20,21]$. Individuals with psychotic disorders utilize more maladaptive coping strategies, especially avoidance and less active coping than healthy control group $[22,23]$. The defence mechanisms are responsible for different ways of coping with emotional difficulties associated with a particular disorder [24].

The dispositional and gender socialization theories suggest that when men and women confront similar stressors, they will behave in different ways because men stereotypically are socialized to conceal their emotions and to be action-oriented [25]. The result of the metaanalysis concerning sex differences in the strategy for coping with stress showed that women were significantly more likely than men to use active coping, planning, to seek emotional and instrumental social support, to use avoidance and religious coping [26]. There were no sex differences in strategy such as denial and venting. Moreover, the previous research concerning mentally ill patients revealed that coping styles differed significantly between females and males. Women suffering from depression were more likely to use avoidant coping strategies than men [19]. Furthermore females suffering from anxiety disorders used more searching support than males [17].

On the basis of the cited results indicating the important role of gender in the disease perception and coping with stress strategies, the theoretical model was proposed in figure 1. In our article there was presented a different understanding of the disease perception than in the CSM model, regarding the functions of mental illness in the individual's life. Taking into account the previous research, we postulate that gender is a potential moderator between the mental disease perception and coping strategies $[15,19,21,26]$. Furthermore, our study was aimed at answering the question which components of the relationship between the coping with stress strategies and mental disease perception are moderated by gender.

Figure 1. The theoretical model of gender role in the relationship between the mental disease perception and strategies for coping with stress

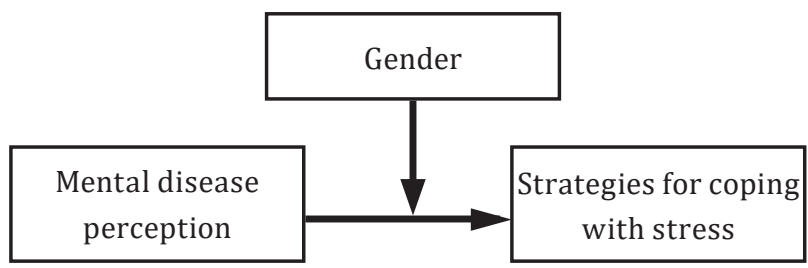

\section{Material and method}

The examinations were carried out in the Antoni Kępiński Specialist Mental Healthcare Centre in Jarosław. The study was conducted individually in compliance with the Declaration of Helsinki. The study was approved by the Ethics Committee of Medical University of Lublin (theproject identification code: KE-0245/133/2014). All participants were informed about the purpose and the anonymity of the study and provided written consent to participate in the research. The criterion for selecting into the study group was differential diagnosis of a mental disorder, according to International Statistical Classification of Diseases and Related Health Problems ICD 10. Five types of mental disorders were selected: depressive disorders (F32, F33), anxiety disorders (F41, F42, F43), alcohol related disorders (F10), schizophrenia (F20). 


\section{Participants}

The study group consisted of 98 patients ( 34 females and 64 males). Those examined included 20 subjects with depressive disorders (F32, F33), 27 with schizophrenia (F20), 21 with anxiety disorders (F41, F42, F43), 30 with alcohol related disorders (F10). The subjects were affected by the mental disorders for a varied length of time, ranging from six months to 39 years, with the mean of $M=11.23$ $(S D=8.49)$. The mean number of hospital stays was $M=4.56(S D=4.51)$, although some of the patients visited psychiatry wards even 30 times. The mean age of patients was approximately 44 years old $(M=43.86 ; S D=11.47)$, the youngest being 22 and the oldest 71 years old. Most patients had completed vocational education (36.93\%), or secondary schools (32.24\%), with considerably lower rates of those with primary and higher education levels $12.09 \%$ and $18.74 \%$, respectively. As many as $49.58 \%$ of the subjects were single, while married people accounted for $34.77 \%$ of the study group, $12.00 \%$ were divorced and $3.66 \%$ were widowed. Residents of rural and urban areas accounted for $56.50 \%$ and $43.50 \%$ of the study group, respectively. As many as $46.39 \%$ of the patients reported welfare benefits as the main source of income. Only $28.58 \%$ of the subjects earned their living owing to paid employment, while $12.75 \%$ of the subjects were unemployed. When it comes to $12.28 \%$ of patients, they declared other income sources.

The study applied two standardised research tools and a socio-demographic survey. The COPE Inventory developed by Ch. S. Carver, M. F. Scheier, and J. K. Weintraub, and adapted by Z. Juczyński and N. OgińskaBulik, is a tool enabling measurement of 15 strategies for coping with stress $[27,28]$. Reliability of COPE for the study group, estimated on the basis of Cronbach's $\alpha$ for the specific scales, was in the range from 0.29 to 0.94 .

The Disease Perception Questionnaire is a psychometric tool proposed by B. Pawłowska and E. Potembska, and designed to assess a self-perceived image of one's condition and attitudes towards the illness. The questionnaire consists of four scales: disease as a threat, weakness, task and benefit [8]. The reliability of the tool was verified taking into account the values of Cronbach's alpha coefficients. In the study group internal compatibility of the tool in the specific scales ranged from 0.82 to 0.89 .

Statistical analyses were computed using SPSS 26 statistics software. The distributions of the relevant parameters were estimated based on Shapiro-Wilk test. The PROCESS Procedure for SPSS Version 3.4 was used in order to investigate the moderation effects [29].

\section{Results}

The proposed moderating effect of gender in reference to the strategy for coping with stress (15 strategies for coping with stress) and disease perception (disease as a threat, weakness, task, benefit) was analysed using the first moderation model according to Hayes [29]. The regression model with 5000 bootstrapping sampling and a 95\% confidence interval was used to estimate the effects. The results of the analysis were presented in table 1.

Table 1. Gender as a moderator of the relationship between disease perception and coping with stress strategy

\begin{tabular}{|c|c|c|c|c|}
\hline \multirow{3}{*}{$\begin{array}{r}\text { Predictors } \\
\text { Disease perception }\end{array}$} & \multirow{2}{*}{\multicolumn{4}{|c|}{$\begin{array}{c}\text { Coping with stress strategy } \\
\text { Acceptance (A) }\end{array}$}} \\
\hline & & & & \\
\hline & $b$ & $(S E)$ & $\begin{array}{l}95 \% \\
L L C I\end{array}$ & $\begin{array}{l}95 \% \\
U L C I\end{array}$ \\
\hline Weakness (W) & $0.13^{*}$ & 0.05 & 0.03 & 0.23 \\
\hline Gender & $2.99^{*}$ & 1.29 & 0.43 & 5.55 \\
\hline (W) $x$ Gender & $-0.10^{* *}$ & 0.04 & -0.17 & -0.03 \\
\hline \multirow[t]{2}{*}{ Model summary } & \multicolumn{4}{|c|}{$\begin{aligned} R^{2}=0.08 M S E & =4.26 F(3.94)=2.63 \\
p & =0.054\end{aligned}$} \\
\hline & \multicolumn{4}{|c|}{$\begin{array}{l}\text { Use of emotional social support } \\
\text { (UESS) }\end{array}$} \\
\hline Weakness (W) & $0.18^{*}$ & 0.08 & 0.02 & 0.35 \\
\hline Gender & $7.28^{* *}$ & 2.11 & 3.08 & 11.47 \\
\hline (W) $x$ Gender & $-0.15^{*}$ & 0.06 & -0.27 & -0.03 \\
\hline \multirow[t]{2}{*}{ Model summary } & \multicolumn{4}{|c|}{$\begin{array}{c}R^{2}=0.15 M S E=11.42 F(3.94)=12.45 \\
p=0.002\end{array}$} \\
\hline & \multicolumn{4}{|c|}{ Religious coping (RC) } \\
\hline Threat (T) & $0.18^{*}$ & 0.00 & 0.01 & 0.34 \\
\hline Gender & $10.81^{* *}$ & 3.47 & 3.92 & 17.70 \\
\hline (T) $x$ Gender & $-0.14^{*}$ & 0.06 & -0.26 & -0.02 \\
\hline Model summary & \multicolumn{4}{|c|}{$\begin{array}{c}R^{2}=0.15 M S E=16.34 F(3.94)=5.43 \\
p=0.002\end{array}$} \\
\hline Benefit (B) & $0.30^{* *}$ & 0.11 & 0.00 & 0.52 \\
\hline Gender & $7.63^{*}$ & 2.91 & 1.85 & 13.40 \\
\hline (B) $x$ Gender & $-0.16^{*}$ & 0.08 & -0.32 & -0.01 \\
\hline \multirow[t]{2}{*}{ Model summary } & \multicolumn{4}{|c|}{$\begin{array}{c}R^{2}=0.19 M S E=15.57 F(3.94)=7.25 \\
p=0.002\end{array}$} \\
\hline & \multicolumn{4}{|c|}{ Planning (P) } \\
\hline Threat (T) & 0.08 & 0.05 & -0.02 & 0.17 \\
\hline Gender & $5.10^{*}$ & 2.05 & 1.02 & 9.18 \\
\hline (T) $\times$ Gender & $-0.09 *$ & 0.04 & -0.16 & -0.02 \\
\hline Model summary & \multicolumn{4}{|c|}{$\begin{array}{c}R^{2}=0.10 M S E=5.73 F(3.94)=3.46 \\
p=0.019\end{array}$} \\
\hline
\end{tabular}

${ }^{*}-p<0.05$; $^{* *}-p<0.01{ }^{* * *}-p<0.001$

The findings showed a statistically significant moderation effect of gender in the relationship between religious coping and disease perception as a benefit (interaction effect $F(3.94)=4.07 ; p=0.047)$. As shown 
in the figure 2, the positive relationship between disease perception as a benefit and religious coping was significant for males $(b=0.14,95 \% C I=[0.06,0.23])$ but not for females $(b=-0.02,95 \% C I=[-0.15,0.11])$. It turned out that as the perception of the mental disease as a benefit increases, the frequency of religious coping increases, specifically for men.

Figure 2. Interaction effect between disease perception as a benefit and gender on the frequency of religious coping

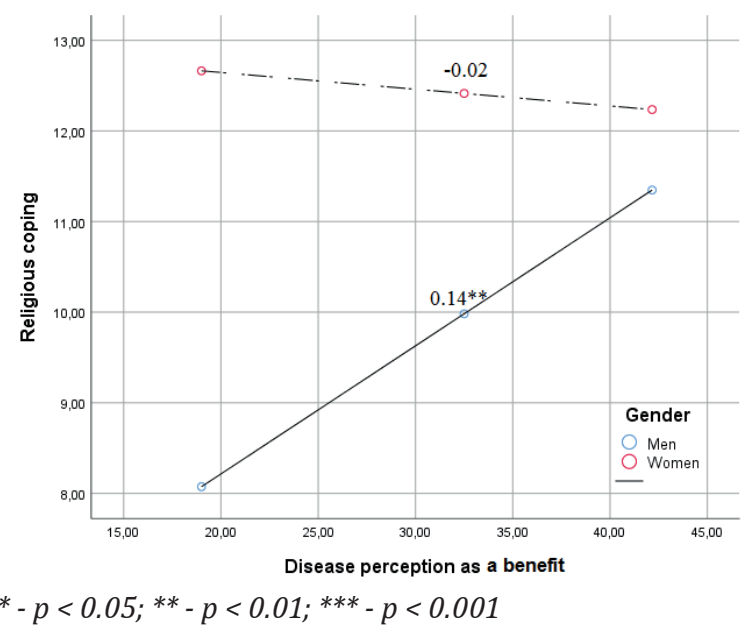

Results revealed that gender moderated the relationship between the use of emotional social support and disease perception as a weakness (interaction effect $F(3.94)=6.40 ; p=0.013)$. As shown in the figure 3 , the negative relationship between disease perception as a weakness and the use of emotional social support was significant for females $(b=-0.12,95 \% C I=[-0.22$, $-0.02]$ ) but not for males ( $b=0.03,95 \% C I=[-0.03,0.10])$. Specifically for women, as the perception of the mental disease as a weakness increases, the frequency of using the emotional social support decreases.

Figure 3. Interaction effect between disease perception as a weakness and gender on the frequency of using of emotional social support

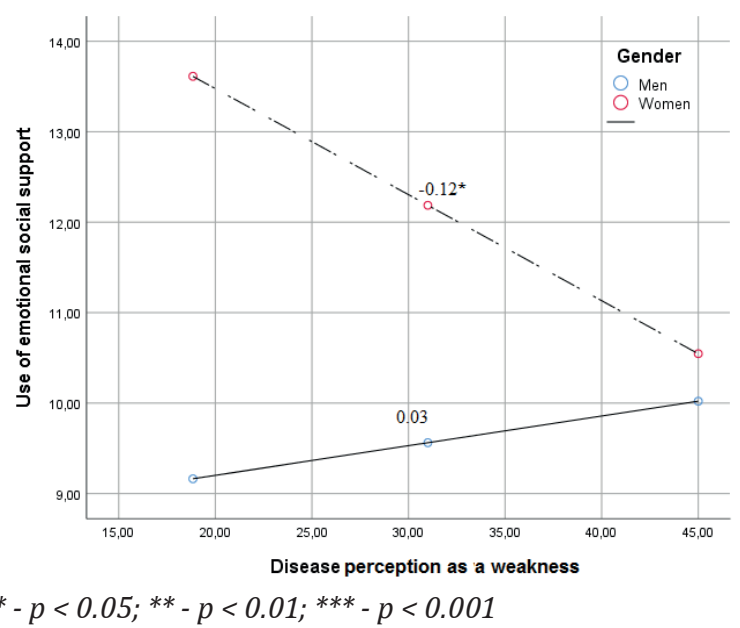

The results showed that gender moderated the relationship between the acceptance strategy and disease perception as a weakness (interaction effect $F(3.94)=7.38 ; p=0.008)$. As shown in Figure 4 , the negative relationship between the disease perception as a weakness and the acceptance strategy was significant for females $(b=-0.07,95 \% C I=[-0.13,-0.01])$ but not for males $(b=0.03,95 \% C I=[-0.02,0.07])$. Specifically for women, as the perception of the mental disease as a weakness increases, the frequency of using acceptance as coping strategy for stress decreases.

Figure 4. Interaction effect between disease perception as a weakness and gender on the frequency of acceptance as coping strategy for stress

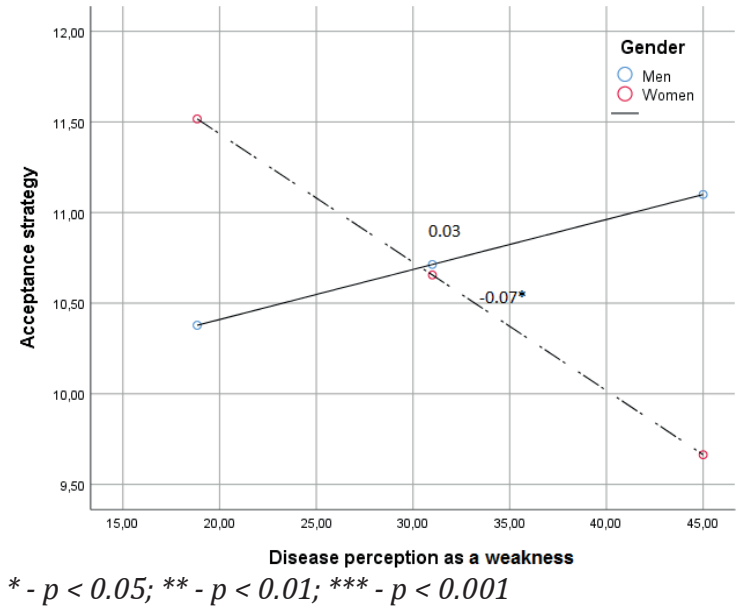

The obtained data showed a statistically significant moderation effect of gender in the relationship between the disease perception as a threat and religious coping (interaction effect $F(3.94)=5.63 ; p=0.019)$. As shown in Figure 5, the negative relationship between the disease perception as a threat and religious coping was significant for females $(b=-0.10,95 \% C I=[-0.20,-0.01])$ but not for males $(b=0.04,95 \% C I=[-0.03,0.10])$. It turned out that

Figure 5. Interaction effect between disease perception as a threat and gender on the frequency of religious coping

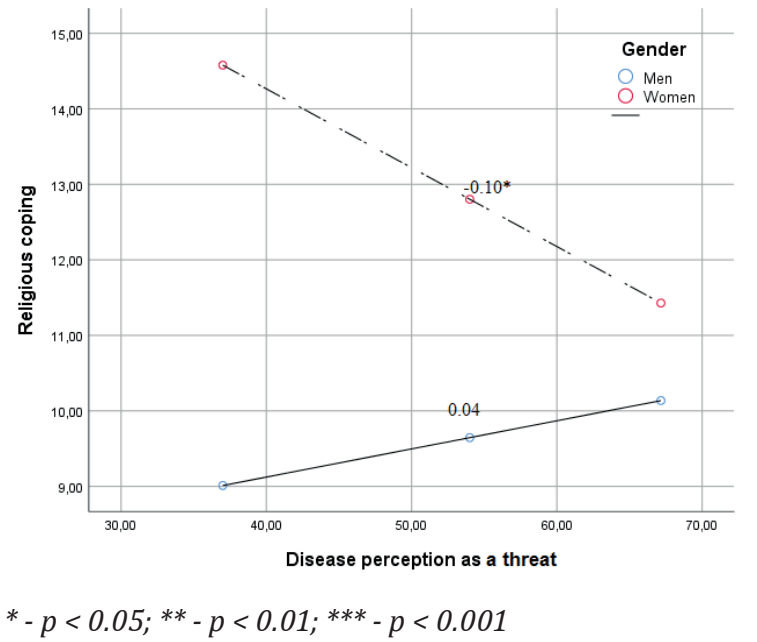


as the perception of the disease as threat decreases, the frequency of religious coping increases, specifically for women.

The results showed that gender moderated the relationship between the disease perception as a threat and planning strategy (interaction effect $F(3.94)=5.82$; $p=0.018$ ). As shown in Figure 6, the negative relationship between the disease perception as a threat and planning strategy was significant for females $(b=-0.09,95 \% C I=$ $[-0.15,-0.04])$ but not for males $(b=-0.01,95 \% C I=[-0.05$, $0.031])$. Specifically for women, as the perception of the disease as threat decreases, the frequency of planning strategy increases.

Figure 6. Interaction effect between disease perception as a threat and gender on the frequency of planning strategy

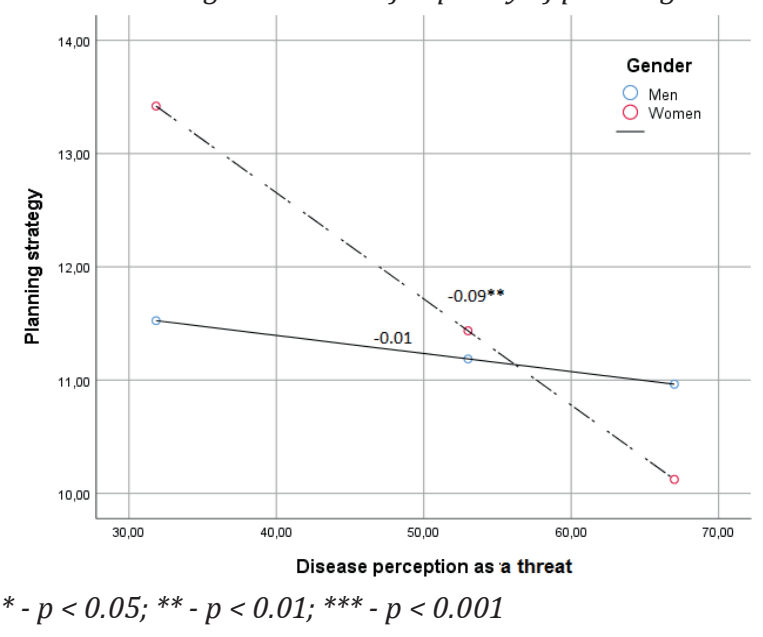

\section{Discussion}

The research aim was to predict whether gender was a potential moderator between mental disease perception and coping strategies. Our results indicated that the relationship between the mental disease perception and coping strategies is different for men and women, and gender was a significant moderator. Gender was the moderator of the relationship between mental disease as a benefit, weakness, threat and religious coping, acceptance, emotional social support, and planning.

Our results indicated that as the perception of the mental disease as a benefit increases, the frequency of religious coping increases, specifically for men. Religious coping strategy is a method of patients' adjustment to their illness. According to the meta-analysis data, females more often use religious coping strategy than males as the reaction to personal health stressor [26]. Our results showed the opposite pattern of sex differences in the situation of treating mental disease as a benefit. Men who perceive their mental disease as a way to get attention and care, have a tendency to pray for guidance or comfort. In other words, the religious coping may be the way to manage emotional or instrumental support for men who need more care and attention. This conclusion is in line with Oliffe et al., whose results indicated that depressive men used religious and moral beliefs to manage distress caused by the experienced symptoms [30].

Furthermore, our results showed that when the perception of the mental disease as a weakness increases, the frequency of using the emotional social support and acceptance decreases, specifically for women. Rating mental illness as a weakness may have a source in the stigmatisation issues [31]. Individuals are ashamed and refuse diagnosis, trivialise the symptoms. On the other hands, it should be emphasised that the level of neuroticism, which is high in individuals with mental disorders, significantly affects the choice of strategies for coping with stress, especially for women [20]. Matheson \& Anisman revealed that the level of anxiety is linked with emotion-focused coping [24, 17]. The metaanalysis outcomes found out that women were more likely than men to engage in seeking emotional support and acceptance when neuroticism was statistically controlled. The mechanism of these strategies was different. There were no sex differences for acceptance without controlling the level of neuroticism while seeking emotional support was still significant [26]. This mechanism may be explained by the fact that women scored higher than men in neuroticism. This conclusion is consistent with the dispositional theory suggesting that there are characteristic differences between males and females reflected in their coping strategy choices [26]. Furthermore, the shame caused by mental illness reduces the seeking of emotional support from others, and neuroticism enhances this effect. The passive acceptance of the mental disease is due to the fact that women are afraid to admit the existence of the problem.

Furthermore, our findings revealed that when the women's perception of the disease as threat the increases, the frequency of religious coping and planning decreases. The gender socialization theory suggests that men might be more likely to be action-oriented, and engage in problem-focused coping, while the opposite pattern is true for females [32,33]. Women have a tendency to focus on the emotion, not the solution. The adaptation to the mental disease strengthens with time, the illness is less frightening. It might be the reason why the probability of adaptive coping increased for women. Our results are consistent with the previous results of meta-analysis indicating that the coping strategy was influenced by the type of stressor. Females were more likely than men to plan as the reaction to personal health stressor [26].

\section{Conclusion}

In summary, the present study showed that there is an opposite pattern of gender specific coping strategy 
dependent on the mental illness perception. When the perception of the mental disease as a benefit increases, the frequency of religious coping increases, specifically for men. The opposite sex pattern revealed that if an individual's perception of illness as a threat increased, women were less likely to use religious coping and planning. Furthermore, as the perception of the mental disease as a weakness increases, the frequency of using of the emotional social support and acceptance decreases in women.

The significant limitation of the study results was the number of male subjects, who accounted for $65 \%$ of the study group. This situation was due to the fact that all alcohol-addict patients were males. In the case of other mental disorders there were equal proportions of men and women. The identified limitations suggest that further research should involve the same numbers of males and females. The findings lead to the questions about mediating effect of the type of mental disorder on the link between the mental disease perception and coping strategies. Additionally, our results have the practical implications in designing interventions aimed at men and women. This work has a potential to lead to the improved understanding of a gender specific behaviour in patients with psychiatric problems. In the context of psychotherapeutic intervention, it may offer new approaches to develop gender specific self-regulation mechanism in relation to the adaptive coping strategy selection by patients $[7,34]$.

\section{Conflict of interest}

The authors have declared no conflict of interest.

\section{References:}

1. American Psychiatric Association (APA). Diagnostic and Statistical Manual of Mental Disorders. 5th ed Washington, DC: APA; 2013.

2. Telles-Correia D, Saraiva S, Gonçalves J. Mental Disorder-The Need for an Accurate Definition. Frontiers in Psychiatry. 2018; 12, 9:64.

3. Petrie KJ, Broadbent E, Kydd R. Illness perceptions in mental health: Issues and potential applications. Journal Mental Health. 2008;17(6):559-564.

4. Chemperek E, Patyrak J, Wieczorski M. Analiza postaw pacjentów wobec choroby. Zdrowie Publiczne. 2008; 118 (3): 259-263.

5. Fortune $\mathrm{G}$, Barrowclough $\mathrm{C}$, Lobban F. Illness representations in depression. British Journal Clinical Psychology. 2004; 43(4):347-364.

6. Leventhal, H., Nerenz, D.R. and Steele, D.J.. Illness representations and coping with health threats. In: Baum, A., Taylor, S.E. and Singer, J.E. (Eds.), Handbook of p s ychology and health: social psychological aspects of health, Vol. 4. pp. 219-252. Earlbaum, Hillsdale, NJ; 1984.

7. Williams K, Steer H. Illness perceptions: are beliefs about mental health problems associated with self-perceptions of engagement in people with psychosis? Behavioral Cognitive Psychotherapy.
2011; 39(2):151-163.

8. Pawłowska B, Potembska E, Pić J, Pić N, Pić K. Właściwości psychometryczne Kwestionariusza do badania Obrazu własnej Choroby Current Problem in Psychiatry. 2016; 17(2), 83-89.

9. Pawłowska B, Międlar K, Biały-Międlar K, Dziurzyńska E. Niepokój a postawy wobec choroby u pacjentek z guzami jajnika i mięśniakami macicy. Current Problem in Psychiatry. 2012; 13 (3): 209-215.

10. Leventhal, H., Meyer, D. and Nerenz, D. The common sense model of illness danger. In: Rachman, S. (Ed.), Medical psychology, 1980; Vol. 2. pp. 7-30. Pergamon, New York.

11. Diefenbach, M. A., \& Leventhal, H.. The Common-Sense Model of Illness Representation: Theoretical and Practical Considerations. Journal of Social Distress and the Homeless, 1996; 5(1), 11-38. doi:10.1007/bf02090456

12. Zhang $\mathrm{M}$, Hong L, Zhang $\mathrm{T}$, Lin $\mathrm{Y}$, Zheng $\mathrm{S}$, Zhou X, et al. Illness perceptions and stress: mediators between disease severity and psychological well-being and quality of life among patients with Crohn's disease. Patient Prefer Adherence. 2016; 10: 2387-2396

13. Lobban, F., Barrowclough, C., \& Jones, S.. The impact of beliefs about mental health problems and coping on outcome in schizophrenia. Psychological Medicine, 2004; 34, 1165-1176.

14. Fortune, G., Barrowclough, C., \& Lobban, F.. Illness representations in depression. British Journal of Clinical Psychology, 2004; 43, 347-364.

15. Bhui, K., Rudell, K., \& Priebe, S.. Assessing explanatory models for common mental disorders. Journal of Clinical Psychiatry, 2006; 67, 964-971.

16. Lysaker PH, Bryson OJ, Marks K, Qreig TC, Bell MD. Coping Style in Schizophrenia: Associations With Neurocognitive Deficits and Personality. Schizophrenia Bulletin. 2004; 30(1): 113-121.

17. Pozzi G, Frustaci A, Tedeschi D, Solaroli,S. Grandinetti P, Di Nicola $M$, et al. Coping strategies in a sample of anxiety patients: factorial analysis and associations with psychopathology. Brain and Behavior, 2015; 5(8), e00351

18. Phillips, L. J., Francey, S. M., Edwards, J., \& McMurray, N.. Strategies used by psychotic individuals to cope with life stress and symptoms of illness: a systematic review. Anxiety, Stress \& Coping, 2009; 22(4), 371-410. doi:10.1080/10615800902811065

19. Sawhney, M., Kunen, S., \& Gupta, A.. Depressive Symptoms and Coping Strategies Among Indian University Students. Psychological Reports, 2018; 003329411882051. doi:10.1177/0033294118820511

20. Vollrath, M., Torgersen, S. \& Alnæs, R.. Neuroticism, coping and change in MCMI-II clinical syndromes: test of a mediator model. Scandinavian Journal of Psychology, 1998; 39, 15-24.

21. Aldao, A., Nolen-Hoeksema, S., \& Schweizer, S.. Emotionregulation strategies across psychopathology: A meta-analytic review. Clinical Psychology Review, 2010; 30(2), 217-237. doi:10.1016/j.cpr.2009.11.004

22. Horan, W.P., \& Blanchard, J.J.. Emotional responses to psychosocial stress in schizophrenia: The role of individual differences in affective traits and coping. Schizophrenia Research, 2003; 60, 271-283.

23. Horan, W.P., Ventura, J., Mintz, J., Kopelowicz, A., Wirshing, D., Christian-Herman, J., et al.. Stress and coping responses to a natural disaster in people with schizophrenia. Psychiatry Research, 2007; 151, 77-86.

24. Matheson K, Anisman H. Systems of Coping Associated with Dysphoria, Anxiety and Depressive Illness: A Multivariate Profile Perspective. Stress. 2003; 6 (3), 223-234.

25. Rosario, M., Shinn, M., Morch, H., \& Huckabee, C. B.. Gender differences in coping and social supports: Testing socialization and role constraint theories. Journal of Community Psychology, 
1988; 16, 55-69.

26. Tamres, L. K., Janicki, D., \& Helgeson, V. S.. Sex differences in coping behaviour: A meta-analytic review and an examination of relative coping. Personality and Social Psychology Review, 2002; 6, 2-30. http://dx.doi.org/10.1207/S15327957PSPR0601_1.

27. Carver, C. S., Scheier, M. F., \& Weintraub, J. J.. Assessing coping strategies: a theoretically based approach. Journal of Personality and Social Psychology, 1989; 56, 267-283.

28. Juczyński Z. Ogińska-Bulik N.. Narzędzia pomiaru stresu i radzenia sobie ze stresem. Warszawa: PTP; 2009.

29. 29. Hayes AF: Introduction to Mediation, Moderation, and Conditional Process Analysis. A Regression Bases Approach. New York, NY, US: A Division of Guilford Publications, Inc.; 2018

30. Oliffe, J. L., Ogrodniczuk, J. S., Bottorff, J. L., Johnson, J. L., \& Hoyak, K. . "You feel like you can't live anymore": Suicide from the perspectives of Canadian men who experience depression. Social Science \& Medicine, 2012; 74, 506-514. http://dx.doi. org/10.1016/j.socscimed.2010.03.057

31. Dinos S, Stevens S, Serfaty M, Weich S, King M. Stigma: the feelings and experiences of 46 people with mental illness. Qualitative study. British Journal Psychiatry. 2004; 184:176181

32. Sprecher, S., \& Sedikides, C.. Gender differences in perceptions of emotionality: The case of close heterosexual relationships. Sex Roles, 1993; 28, 511-530.
33. Fujita, F., Diener, E., \& Sandvik, E.. Gender differences in negative affect and well-being: The case for emotional intensity. Journal of Personality and Social Psychology, 1991; 61, 427-434.

34. Ociskova M, Prasko J, Kamaradova D, Grambal A, Kasalova P. Sigmundova Z. et al. Coping strategies, hope, and treatment efficacy in pharmacoresistant inpatients with neurotic spectrum disorders. Neuropsychiatric Disease and Treatment. 2015; 11, 1191-1201.

\section{Corresponding author}

mgr Wioletta Ozga

Institute of Psychology, The John Paul II Catholic

University of Lublin

w.k.ozga@gmail.com

Al. Racławickie 14, 20-950 Lublin, Poland

Otrzymano: 03.05.2020

Zrecenzowano:08.06.2020

Przyjęto do druku: 26.06.2020 